\title{
INFLUENCE OF CROP ROTATION AND METEOROLOGICAL CONDITONS ON BIODIVERSITY OF WEED COMMUNITIES IN SPRING BARLEY (Hordeum vulgare L.)
}

\author{
Magdalena Jastrzębska, Maria Wanic, Marta K. Kostrzewska \\ University of Warmia and Mazury in Olsztyn, Chair of Agricultural Systems, \\ 10-718 Olsztyn, pl. Łódzki 3, Poland \\ e-mail: jama@uwm.edu.pl; mwanic@uwm.edu.pl; marta.kostrzewska@uwm.edu.pl
}

Received: 8.01.2010

\begin{abstract}
The paper presents the analysis of changes in weed biodiversity in spring barley cultivated in the years 1990-2004 in crop rotation with a $25 \%$ proportion of this cereal (potato - spring barley - sowing peas - winter triticale), when it was grown after potato, and in crop rotation with its $75 \%$ proportion (potato - spring barley - spring barley - spring barley), when it was grown once or twice after spring barley. In the experiment, no weed control was applied. Every year in the spring (at full emergence of the cereal) and before the harvest, the composition of weed species and numbers of particular weed species were determined, and before the harvest also their biomass. On this basis, the constancy of species in particular years, Shannon-Wiener species diversity indices and diversity profiles according to Rényi were determined. Weed species richness increased linearly at all plots during the 15-year period. Chenopodium album was a constant and dominant species in terms of weed species density and biomass year after year. The quality of the plot had no clear influence on the diversity of weeds in barley. Weed density and biomass showed high year-to-year variability and a positive correlation with the amount of precipitation and a negative correlation with temperature during the period of the study. The significance of the correlation between the productivity of barley and weed diversity was not confirmed.
\end{abstract}

Key words: spring barley, crop rotation, air temperature, precipitation, weed species, constancy, Shannon-Wiener index, Rényi profiles, year-to-year changes

\section{INTRODUCTION}

Contemporary weed growth control on cultivated fields is facing a dilemma how to reconcile the needs of crop protection and the need for protection of biodiversity. Competition between weeds and crops in relation to habitat resources is obvious and undoubted. Weeds can also be hosts for numerous pests and pathogens; they make the harvest more difficult and worsen the yields (Skrzypczak and Adamczewski, 2002). For years that perception of weeds resulted in a situation where efforts were undertaken to eliminate them at any price. At the same time, intensification of farming in agro-ecosystems supported intensified expansion of segetal plants, coupled with unfavourable changes in the communities in the direction of compensation for some species (H y v ö n e n, 2004; A d a m i a k, 2007). Only relatively recently a perception started to develop that the above measures might result in the impoverishment of the diversity of the world of organisms in those ecosystems. This applies to both weeds themselves and organisms related to them by trophic and para-trophic relations (Andreasen and Stryhn, 2008). Many once common weed species are on the list of species that are extinct or threatened by extinction (Cheffings and Farre 11, 2005; Zarzycki and M ire k, 2006; T ü re and B ö c ü k, 2008). Increasingly often the positive role of weeds in agrocenoses is noticed as well as the possibility of using them in many aspects of human life (H o c h ó 1 , 2003).

Identification and preservation of species richness of the biosphere, in addition to clearly knowledge development aspects, have also a purely practical meaning for man as well as ethical and aesthetic importance. Investigation and protection of biodiversity are the duty of the countries that signed the relevant convention in 1992. Since the 1960s, there has been an ongoing debate about the correlation between species diversity in ecosystems and their functional stability and productivity (Lehman and Tilman, 2000; McCann, 2000; Hooper et al. 2005; Smith et al. 
2008). In this aspect, not only the number of species in the community of organisms is important, but also the quantitative proportions among them. Proving the above-mentioned correlations has a special dimension in relation to agricultural ecosystems, that is, the systems focused on high yield of biomass per area unit and influenced by systematic destructive human intervention. The biodiversity of cultivated fields is divided into "planned" and "associated" (Alti e ri, 1999). Weeds represent an important component of the latter one, however, as opposed to communities rich with species such as, e.g., meadows, the species diversity of plants accompanying crops on arable land has so far been subject to much less attention ( $\mathrm{H} \mathrm{y} \mathrm{v} \mathrm{ö} \mathrm{n} \mathrm{e} \mathrm{n,}$ 2004). In agricultural studies, the number of species has been and still is the most frequently applied measure for weed biodiversity (B l e c h a r c z y k et al. 2000; Buczyński and Marks, 2003; L os os ová et al. 2004; A d a miak, 2007; Ka a r and Freye r, 2008); assessment using measures considering quantitative proportions among species has appeared in papers less frequently and only since recently (Stevenson et al. 1997, Wesołowski et al. 2003; Jędruszczak and Antoszek, 2004; Stupnicka-Rodzynkiewicz et al. 2004; Wanic et al. 2005; Jastrzębska et al. 2006; Fe led y n-S z ew c z y k, 2008). Numerous studies indicate that harmful effects of a community consisting of a few weed species are often greater than of a community consisting of several or more components (Stupnicka-Rodzynkiewicz et al. 2004). Weed control should be currently represented mainly not by their total elimination but by maintaining their presence at a certain harmless level and preventing compensation.

The aim of the presented work is to present the analysis of weed infestation changes in unprotected spring barley cultivated for 15 years in extreme positions, in terms of quality, with regard to the density of weeds and their biomass. An attempt was also undertaken to determine the correlation between cereal yield and biodiversity of weed communities.

\section{MATERIALS AND METHODS}

The full details of the experiment are reported in the publication by $\mathrm{W}$ an i c et. al. (2010). The results concerning density (in spring and before harvest) and biomass (before harvest) of spring barley (Hordeum vulgare $\mathrm{L}$.) weed communities served to determine species richness (number of species) of weeds, computation of species constancy (B ra u n-B la nquet, 1964), Shannon-Wiener species diversity index (S hannon, 1948; Wi ener, 1948) and diversity profiles according to Rényi (R én y i 1961). The Shannon-Wiener indices and Rényi profiles were determined on the basis of the number of individuals representing individual species in the weed community and biomass generated by each of the species.

In determining the species constancy, the phytosociological constancy method identifying classes according to the Braun-Blanquet cover-abundance scale was applied: $\mathrm{V}$ - species occurring constantly and frequently (present in $80.1-100 \%$ of years covered), IV - frequent species (in 60.1-80\%), III - medium frequent (40.1$60 \%)$, II - not very frequent (20.1-40\%) and I - occasional or rare $(0.1-20 \%$ of the years).

The Shannon-Wiener species diversity index (H') was computed for each year and time of determination by applying the formula:

where:

$$
\mathrm{H}^{\prime}=-\sum\left(p_{i} \cdot \ln p_{i}\right)
$$

$p_{i}$ - proportion of the number of $i$-species individuals in the community (or biomass generated by species $i$ ) to the number (or biomass) of all individuals in the community.

Rényi profiles were determined for communities formed artificially on the basis of average values for the 15-year period for individual species and for actual communities from the extreme years of the studies (1991 and 2004), for the purpose of comparing the diversity of communities at different positions. In that way, the communities developing at the same positions at the beginning and the end of the study were also compared. 1991, which is the year during which two replications of spring barley after spring barley could be recorded, was assumed to represent the starting year of the study. The following formula was applied for computations:

where:

$$
\mathrm{H}_{\alpha}=\left(\ln \Sigma p_{\mathrm{i}}^{\alpha}\right)(1-\alpha)^{-1}
$$

$p_{i}-$ as in Shannon-Wiener formula, $a-$ diversity levels assuming that $a \geqslant 0, a \neq 1$. For $a=1$ in the formula the values of $\mathrm{H}^{\prime}$ were substituted.

The correlation between the studied characteristics of weed communities and the amount of precipitation and average temperatures during the study period was determined by applying the linear correlation coefficients. The linear year-to-year trends were determined for the studied characteristics of weed communities. The linear correlation between weed diversity and barley yield was also analyzed. Those linear trends were determined according to the formula:

$$
y=\mathrm{a}+\mathrm{b} \cdot x
$$

where:

$x$ - value of independent variable (here: consecutive years of study, yield) 
$y$ - value of the dependent variable corresponding to the value of $x$ (here: species richness, Shannon-Wiener diversity index)

a - regression constant (free expression) - determines the intersection point of the determined regression straight with the dependent variable axis $y$

$\mathrm{b}$ - tangent of the slope of regression axis relative to the independent variable $x$ axis; it indicates by how much the dependent variable $y$ will change if the independent variable $x$ changes by one unit.

The Latin names of the weeds followed M i r e k et al. (1995).

\section{RESULTS}

During the 15 years of the study, a total of 35 weeds species were identified in barley (Table 1), 32 of them were identified in the position after potato (crop rotation $\mathrm{A}$ ) and 31 species in case of each of the positions once and twice following spring barley (rotation system B). In all three treatments, Chenopodium album predominated in terms of the number and weight in the communities of weeds, while during the spring period Thlaspi arvense was also represented in high numbers. Those species, germinating early and with relatively short vegetation periods, decreased significantly in numbers before harvest (many individuals died out after reaching maturity and dropped out from the community), although Chenopodium maintained its first position as regards the number of individuals and biomass, while Thlaspi gave precedence to the following species: Stellaria media, Fallopia convolvulus, Sonchus arvensis and Matricaria maritima ssp. inodora. The species: Chenopodium album, Thlaspi arvense, Stellaria media, Matricaria maritima ssp. inodora, Fallopia convolvulus and Galium aparine (in the first crop after barley), appeared in the communities constantly. The most numerous group consisted of species occurring rarely: 13 species were found in the community after potato, whereas 9 and 10 species, respectively, in the first and second barley crops after barley. Similar proportions between permanent and occasional species in the plots changed in relation to other groups. In the position after potato, only one species was included in class II and in the position with the first barley crops after barley only two species were allocated to class IV.

The number of species (species richness) in individual communities and seasons was much smaller as compared to the list of all species found during the 15 -year period. The actual abundance of species in the weed communities varied within the range of 5-19 in the spring and 4-20 before harvest (Table 2). In case of the spring, attention is drawn by a slightly lower threshold of variability in the positions after barley than in the position after potato and the lower coefficient in the latter treatment. It is characteristic that year-to-year differences are larger than the differences between positions (Fig. 1). With the existing variability over time, both in the spring (with the exception of the position after potato) and before the harvest we succeeded in confirming the increase in the number of species during the study period (significant trends). The correlation coefficients before the harvest were higher than during the spring season. In the spring the largest number of species was usually determined in the position after potato, which translated into slight differences between the averages for 15 years. The average number of species decreased, although by not much, with deterioration of the position. During the time before harvest, on average slightly fewer species occurred at the position after the cultivation of barley for one year, but still during the 15 years of the experiment on five occasions the highest number of species of all the three positions was recorded in that position.

The species richness in the spring was positively correlated with the quantity of precipitation in April and before harvest it correlated positively with precipitation in June and negatively with temperature in July and August; it also correlated positively with precipitation and negatively with temperature for the period of April-August (Table 3).

The Shannon-Wiener index is considered one of the best measures of functional biodiversity in communities of organisms. The average values of that index for 15 years show that the largest diversity of communities developed in the position after potato; this applied to both the spring measurement and the measurement before the harvest and in the latter case it applied to both characteristics (density and biomass) assumed as the base of computations (Table 2). It is symptomatic that the Shannon-Wiener index computed on the base of biomass decreased systematically with the deterioration of the position, while according to the index value based on the density, the positions after barley (both of them) practically did not differ in biodiversity. Despite relatively low coefficients of year-to-year variability, the ranges of the index value for individual positions and times were rather wide, as the maximum values were more than twice higher than the minimum. The variation in year-to-year values of the Shannon-Wiener index was very dynamic (Fig. 1) and only in the position where spring barley was cultivated twice after spring barley, before the harvest, it assumed the character of a positively directed trend (confirmed by the applicable correlation coefficients - Table 2). Biodiversity increased under the conditions of higher precipitation and decreased with the increase of temperature during the vegetation period (Table 3 ). 
Table 1

Composition of weed communities in spring barley, weed density and biomass per $1 \mathrm{~m}^{2}$, average for the years $1990-2004$ and species constancy $(\mathrm{S})$ during the years of the experiment

\begin{tabular}{|c|c|c|c|c|c|c|c|c|c|c|c|c|}
\hline \multirow{5}{*}{ Weed species } & \multicolumn{12}{|c|}{ Position (crop rotation - previous crop) } \\
\hline & \multicolumn{4}{|c|}{ A-p } & \multicolumn{4}{|c|}{$\mathrm{B}-\mathrm{b}$} & \multicolumn{4}{|c|}{$\mathrm{B}-\mathrm{bb}$} \\
\hline & \multirow{2}{*}{\multicolumn{2}{|c|}{$\begin{array}{c}\text { density } \\
\text { plants } \mathrm{m}^{-2}\end{array}$}} & \multirow{2}{*}{$\begin{array}{l}\text { biomass } \\
\mathrm{g} \mathrm{m}^{-2}\end{array}$} & \multirow{3}{*}{$\mathrm{S}$} & \multirow{2}{*}{\multicolumn{2}{|c|}{$\begin{array}{c}\text { density } \\
\text { plants } \mathrm{m}^{-2}\end{array}$}} & \multirow{2}{*}{$\begin{array}{l}\text { biomass } \\
\mathrm{g} \mathrm{m}^{-2}\end{array}$} & \multirow{3}{*}{$\mathrm{S}$} & \multirow{2}{*}{\multicolumn{2}{|c|}{$\begin{array}{c}\text { density } \\
\text { plants } \mathrm{m}^{-2}\end{array}$}} & \multirow{2}{*}{$\begin{array}{l}\text { biomass } \\
\mathrm{g} \mathrm{m}^{-2}\end{array}$} & \multirow{3}{*}{$\mathrm{S}$} \\
\hline & & & & & & & & & & & & \\
\hline & spring & befor & harvest & & spring & befor & harvest & & spring & before & harvest & \\
\hline Chenopodium album & 109.2 & 53.5 & 23.32 & $\mathrm{~V}$ & 113.9 & 52.2 & 32.16 & $\mathrm{~V}$ & 99.5 & 57.2 & 40.16 & $\mathrm{~V}$ \\
\hline Thlaspi arvense & 77.3 & 6.9 & 6.05 & $\mathrm{~V}$ & 75.6 & 4.3 & 5.92 & $\mathrm{~V}$ & 89.1 & 6.3 & 4.86 & $\mathrm{~V}$ \\
\hline Stellaria media & 25.8 & 11.8 & 13.66 & $\mathrm{~V}$ & 24.5 & 10.4 & 13.67 & $\mathrm{~V}$ & 30.6 & 12.1 & 14.10 & $\mathrm{~V}$ \\
\hline Matricaria maritima ssp. inodora & 11.9 & 7.8 & 6.92 & $\mathrm{~V}$ & 7.1 & 5.4 & 6.91 & $\mathrm{~V}$ & 8.3 & 5.2 & 4.70 & $\mathrm{~V}$ \\
\hline Fallopia convolvulus & 10.8 & 21.5 & 12.44 & $\mathrm{~V}$ & 17.7 & 23.9 & 12.66 & $\mathrm{~V}$ & 12.7 & 23.6 & 13.57 & $\mathrm{~V}$ \\
\hline Sonchus arvensis & 4.9 & 7.9 & 10.55 & III & 8.0 & 13.4 & 16.86 & III & 9.4 & 11.9 & 17.66 & IV \\
\hline Equisetum arvense & 4.9 & 3.3 & 3.27 & III & 0.7 & 2.7 & 2.87 & II & 0.7 & 5.5 & 9.41 & II \\
\hline Capsella bursa-pastoris & 4.1 & 7.0 & 2.48 & IV & 4.8 & 8.1 & 2.10 & IV & 3.5 & 7.1 & 4.30 & IV \\
\hline Galium aparine & 3.9 & 1.7 & 0.58 & IV & 5.5 & 2.2 & 1.31 & $\mathrm{~V}$ & 4.5 & 5.3 & 2.59 & IV \\
\hline Viola arvensis & 3.3 & 2.1 & 0.50 & IV & 3.2 & 1.8 & 0.79 & IV & 1.8 & 0.8 & 0.37 & IV \\
\hline Lamium amplexicaule & 3.1 & 0.4 & 0.00 & IV & 2.2 & 0.5 & 0.00 & III & 2.6 & 1.3 & 0.13 & IV \\
\hline Myosotis arvensis & 3.0 & 4.7 & 2.02 & IV & 0.9 & 0.8 & 0.35 & II & 0.7 & 1.0 & 0.52 & III \\
\hline Polygonum laphathifolium & 1.9 & 2.6 & 1.33 & IV & 3.5 & 2.4 & 2.44 & II & 1.1 & 3.9 & 1.38 & II \\
\hline Fumaria officinalis & 1.7 & 0.1 & 0.05 & IV & 1.7 & 0.1 & 0.00 & III & 1.5 & 0.3 & 0.19 & III \\
\hline Spergula arvensis & 1.6 & 1.9 & 0.42 & III & 1.9 & 0.6 & 0.01 & III & 4.1 & 0.4 & 0.08 & III \\
\hline Echinochloa crus-galli & 1.3 & 2.3 & 0.56 & II & 0.1 & 0.8 & 0.47 & $\mathrm{I}$ & 0.1 & 0.2 & 0.02 & I \\
\hline Veronica arvensis & 1.2 & 2.9 & 0.47 & III & 3.4 & 2.5 & 0.54 & III & 5.3 & 2.8 & 0.96 & III \\
\hline Plantago major & 0.9 & 0.9 & 0.03 & I & 0.0 & 0.1 & 0.01 & I & 0.5 & 0.5 & 0.04 & II \\
\hline Vicia hirsuta & 0.5 & 0.4 & 0.34 & I & 0.3 & 0.4 & 0.18 & I & 0.7 & 0.4 & 0.56 & II \\
\hline Polygonum aviculare & 0.4 & 5.1 & 2.07 & III & 0.1 & 2.7 & 1.18 & III & 1.2 & 3.1 & 3.87 & III \\
\hline Sinapis arvensis & 0.3 & & & I & 0.4 & & & II & 0.3 & & & I \\
\hline Galeopsis tetrahit & 0.3 & & & I & 0.2 & & & $\mathrm{I}$ & & 0.3 & 0.23 & I \\
\hline Apera spica-venti & 0.2 & & & I & 0.6 & & & $\mathrm{I}$ & 0.3 & & & I \\
\hline Galinsoga parviflora & 0.2 & 4.1 & 0.92 & III & 3.2 & 4.8 & 0.70 & II & 7.3 & 6.7 & 1.68 & III \\
\hline Erodium cicutarium & 0.1 & 0.2 & 0.23 & I & 0.1 & 0.2 & 0.08 & I & 0.3 & & & I \\
\hline Papaver rhoeas & 0.1 & & & I & & & & & 0.1 & & & I \\
\hline Myosurus minimus & 0.1 & & & I & 0.1 & & & I & & & & \\
\hline Anchusa arvensis & & 0.3 & 0.19 & I & 0.1 & 0.2 & 0.35 & $\mathrm{I}$ & 0.2 & 0.1 & 0.16 & II \\
\hline Cirsium arvense & & & & & 0.6 & 0.9 & 3.41 & II & 0.1 & 0.5 & 1.07 & I \\
\hline Crepis tectorum & & 0.7 & 0.32 & I & & 1.2 & 0.50 & I & & 0.1 & 0.00 & I \\
\hline Avena fatua & & 0.1 & 0.16 & I & & & & & & & & \\
\hline Raphanus raphanistrum & & 0.1 & 0.15 & I & & 0.9 & 0.96 & II & & 0.5 & 0.77 & I \\
\hline Arenaria serpyllifolia & & 0.1 & 0.00 & I & & & & & & & & \\
\hline Conyza canadensis & & & & & & 0.2 & 0.00 & II & & & & \\
\hline Poa annua & & & & & & & & & & 0.2 & 0.06 & I \\
\hline
\end{tabular}

Position of the spring barley (position): A-p - in crop rotation A after potato, B-b - in crop rotation B the first time after spring, $\mathrm{B}-\mathrm{bb}$ - in crop rotation $\mathrm{B}$ the second time after spring barley 
Table 2

Weed biodiversity in spring barley and its variability expressed using simple statistics

\begin{tabular}{|c|c|c|c|c|c|c|}
\hline $\begin{array}{l}\text { Weed community } \\
\text { characteristic }\end{array}$ & $\begin{array}{c}\text { Position } \\
\text { (crop rotation } \\
\text { - previous crop) }\end{array}$ & $\begin{array}{l}\text { Average } \\
\text { for } 15 \text { years }\end{array}$ & Min. - max & $\mathrm{V}, \%$ & $\begin{array}{l}\text { Equation of the linear } \\
\text { year-to-year trend }\end{array}$ & $\mathrm{r}$ \\
\hline \multicolumn{7}{|c|}{ spring } \\
\hline Species richness & A-p & 12.0 & $9.0-19.0$ & 24.9 & $y=0.2429 x+10.057$ & 0.31 \\
\hline \multirow{5}{*}{$\mathrm{H}_{\text {density }}$} & $\mathrm{B}-\mathrm{b}$ & 11.1 & $5.0-17.0$ & 32.5 & $y=0.5036 x+7.0381$ & $0.63 *$ \\
\hline & B-bb & 10.7 & $7.0-19.0$ & 33.2 & $y=0.4607 x+6.981$ & $0.58 *$ \\
\hline & $A-p$ & 1.58 & $1.02-2.20$ & 23.3 & $\mathrm{y}=0.0121 \mathrm{x}+1.481$ & 0.15 \\
\hline & $\mathrm{B}-\mathrm{b}$ & 1.53 & $0.98-2.26$ & 24.1 & $y=0.0381 x+1.2216$ & 0.46 \\
\hline & $\mathrm{B}-\mathrm{bb}$ & 1.53 & $1.03-2.04$ & 21.3 & $\mathrm{y}=0.0344 \mathrm{x}+1.2578$ & 0.49 \\
\hline \multicolumn{7}{|c|}{ before harvest } \\
\hline \multirow[t]{3}{*}{ Species richness } & $A-p$ & 10.5 & $5.0-18.0$ & 34.9 & $y=0.6607 x+5.2476$ & $0.80 *$ \\
\hline & $\mathrm{B}-\mathrm{b}$ & 9.9 & $4.0-20.0$ & 41.6 & $y=0.5893 x+5.1524$ & $0.64 *$ \\
\hline & $\mathrm{B}-\mathrm{bb}$ & 10.5 & $5.0-16.0$ & 37.3 & $y=0.6214 x+5.4952$ & $0.71 *$ \\
\hline \multirow[t]{3}{*}{$\mathrm{H}_{\text {density }}^{\prime}$} & $A-p$ & 1.70 & $0.92-2.47$ & 28.8 & $y=0.0546 x+1.2586$ & 0.50 \\
\hline & $\mathrm{B}-\mathrm{b}$ & 1.60 & $0.73-2.44$ & 29.3 & $y=0.0381 x+1.2216$ & 0.51 \\
\hline & $\mathrm{B}-\mathrm{bb}$ & 1.59 & $0.74-2.30$ & 29.6 & $y=0.0344 x+1.2578$ & $0.60 *$ \\
\hline \multirow{3}{*}{$\mathrm{H}_{\text {biomass }}^{\prime}$} & $A-p$ & 1.62 & $0.95-2.19$ & 21.0 & $y=0.0175 x+1.4809$ & 0.23 \\
\hline & $\mathrm{B}-\mathrm{b}$ & 1.58 & $0.81-2.04$ & 21.7 & $\mathrm{y}=0.037 \mathrm{x}+1.2834$ & 0.48 \\
\hline & $\mathrm{B}-\mathrm{bb}$ & 1.54 & $0.83-2.20$ & 27.1 & $y=0.0727 x+0.9556$ & $0.78 *$ \\
\hline
\end{tabular}

V- year-to-year variability coefficient, $\mathrm{r}$ - linear correlation coefficient determining the significance of the year-to-year linear trend; * $-\mathrm{r}$ significant at $\mathrm{p}=0.05$; position of the spring barley (position): A-p - in crop rotation A after potato, B-b - in crop rotation $\mathrm{B}$ the first time after spring barley, $\mathrm{B}-\mathrm{bb}$ - in crop rotation B the second time after spring barley; $\mathrm{H}_{\text {density }}$ - Shannon-Wiener diversity index computed on the basis of weed density, $\mathrm{H}_{\text {biomass }}$ - Shannon-Wiener diversity index computed on the basis of weed biomass

Table 3

Linear correlation ratios between weed biodiversity indicators and precipitation $(\mathrm{mm})$ and temperatures $\left({ }^{\circ} \mathrm{C}\right)$ during the study period

\begin{tabular}{|c|c|c|c|c|}
\hline & \multirow{2}{*}{ Item } & \multirow{2}{*}{$\begin{array}{l}\text { Weed species } \\
\text { richness }\end{array}$} & \multicolumn{2}{|c|}{ Indexes } \\
\hline & & & $\mathrm{H}_{\text {density }}^{\prime}$ & $\mathrm{H}_{\text {biomass }}$ \\
\hline \multicolumn{5}{|c|}{ spring (tillering stage) } \\
\hline \multirow[t]{2}{*}{ April } & - precipitation & $0.45^{*}$ & $0.40^{*}$ & \\
\hline & - air temperature & -0.22 & -0.22 & \\
\hline \multicolumn{5}{|c|}{ before harvest (end of vegetation) } \\
\hline \multirow[t]{2}{*}{ May } & - precipitation & 0.25 & 0.14 & 0.08 \\
\hline & - air temperature & -0.15 & -0.27 & -0.16 \\
\hline \multirow[t]{2}{*}{ June } & - precipitation & $0.50 *$ & $0.48 *$ & 0.20 \\
\hline & - air temperature & -0.14 & $-0.42^{*}$ & $-0.43^{*}$ \\
\hline \multirow[t]{2}{*}{ July } & - precipitation & 0.15 & $0.39 *$ & $0.38 *$ \\
\hline & - air temperature & $-0.30 *$ & $-0.66^{*}$ & $-0.61 *$ \\
\hline \multirow[t]{2}{*}{ August } & - precipitation & 0.00 & 0.15 & 0.11 \\
\hline & - air temperature & $-0.60 *$ & $-0.55^{*}$ & $-0.42 *$ \\
\hline \multirow[t]{2}{*}{ April-August } & - precipitation & $0.52 *$ & $0.63^{*}$ & $0.43 *$ \\
\hline & - air temperature & $-0.62 *$ & $-0.87 *$ & $-0.73^{*}$ \\
\hline
\end{tabular}

$\mathrm{H}_{\text {density }}$ - Shannon-Wiener diversity index computed on the basis of weed density; $\mathrm{H}_{\text {biomass }}$ - Shannon-Wiener diversity index computed on the basis of weed biomass; * - correlation significant at $\mathrm{p}=0.05$ 

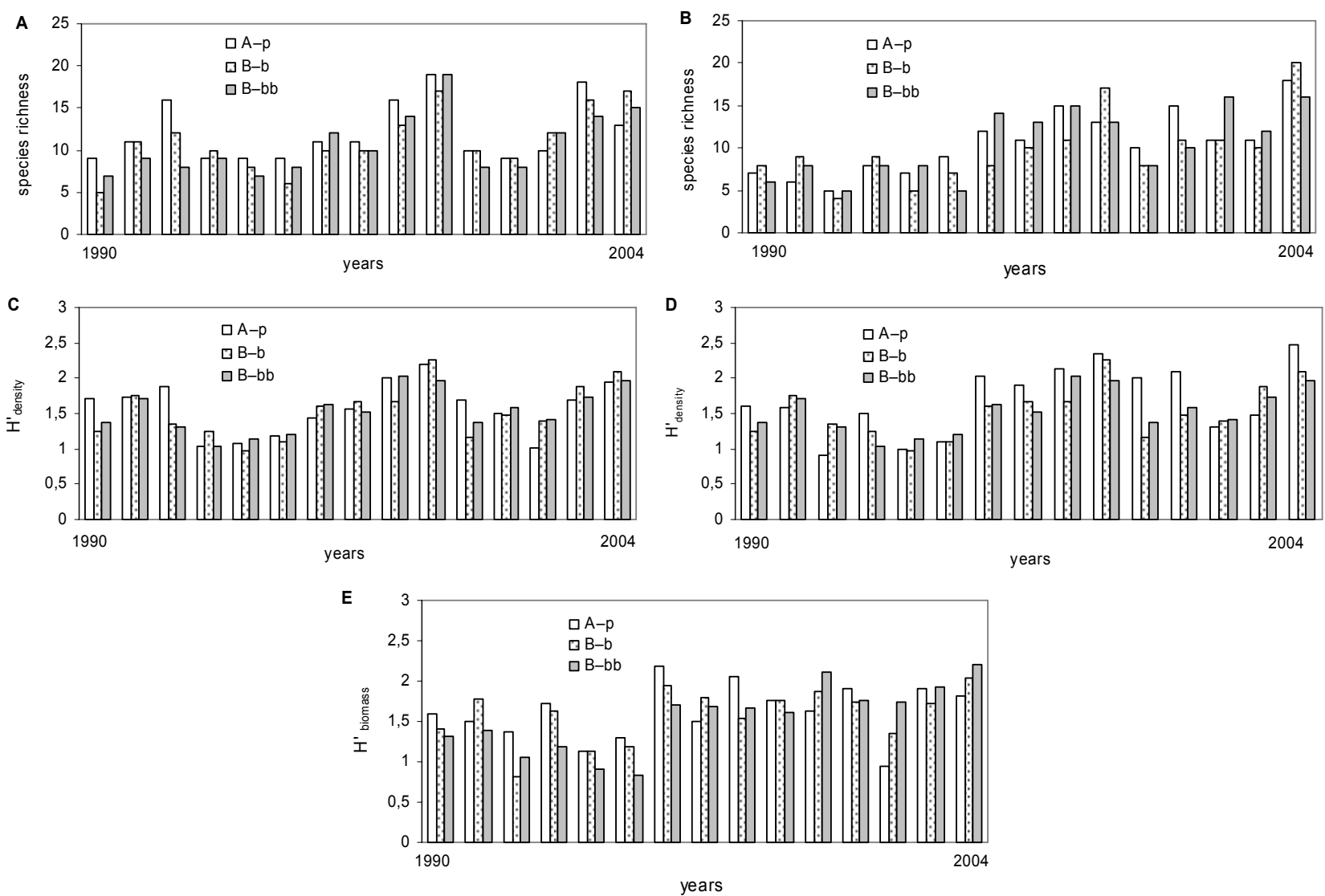

Fig. 1. Diversity of weeds species in spring barley field during the years 1990-2004; (A, C) in the spring, (B, D, E) before barley harvest; position of spring barley (position): A-p - in crop rotation A after potato, B-b - in crop rotation B the first time after spring barley, B-bb - in crop rotation B the second time after spring barley; H'density -Shannon-Wiener diversity index computed on the bases of weed density, $\mathrm{H}^{\prime}$ biomass - Shannon-Wiener diversity index computed on the bases of weed biomass

Rényi profiles determined for artificial formations built on the basis of the averages from 15 years of the studies show high analogy of the compared positions as concerns biodiversity (Fig. 2). The corresponding curves almost overlap with one another. For the extreme years of study, this analysis was also conducted for the actual communities. At the start of the study period (1991), the spring communities formed at the analyzed positions were incomparable according to Rényi's theory. And before the harvest the communities in the position after barley were more bio-diversified, in terms of both density and biomass, than the communities in the other two positions, and those two did not allow their organization according to the Rényi system. In 2004 the spring communities in both positions after barley differed in biodiversity at all levels in favor of the first crop after spring barley. The communities from the treament after potato could not be compared with the other two. Before barley harvest, the communities developed after potato and after barley (one consecutive crop) were incompa- tible, but both were more diversified than that which formed in barley cultivated for the second time after barley; it was not possible to compare them according to the Rényi system if biomass was taken as the base for computation of the family of biodiversity indicators.

In the analysis of the communities formed in the same positions and at the same times in 1991 with 2004 (Fig. 3), it was established that in the plot after potato, in terms of density (in the spring and before harvest), the community of 2004 was more diversified, while in the case that weed biomass was assumed as the base the curves intersected by the alpha positioned between levels 1 and 2. In the positions after barley once and twice, the curves obtained for the spring dates intersect, while before the harvest the communities found in 2004 proved to be more diversified at all alpha levels than in 1991 (taking for the base for computation of the family of indicators both the density of individuals representing different species and the biomass generated). 
The significance of correlation between the productivity of barley and weed diversity expressed by the number of species and the Shannon-Wiener index

value, irrespective of the base of its determination, was not confirmed (Fig. 4).
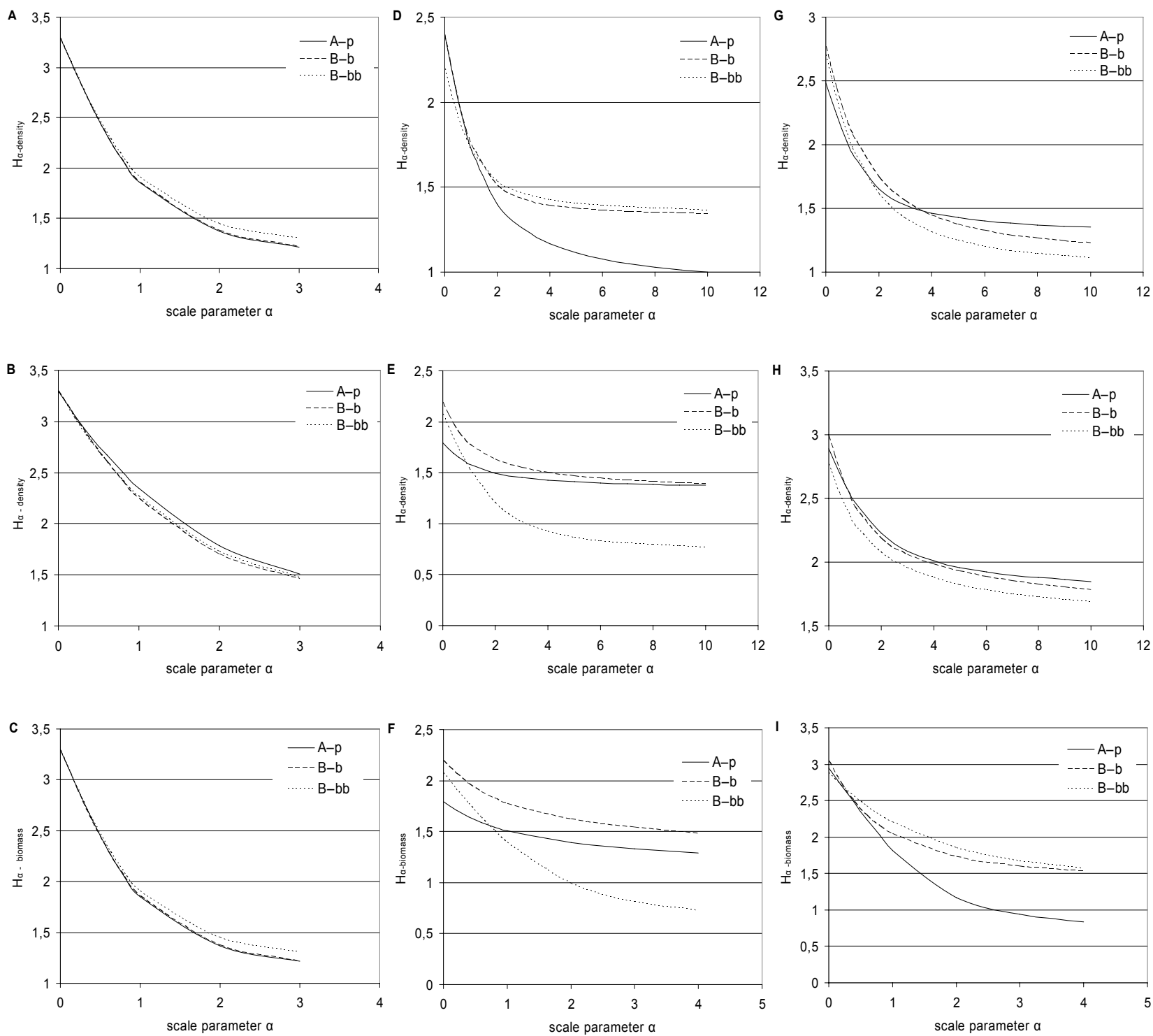

Fig. 2. Diversity profiles according to Rényi established for „artificial” communities of weeds formed on the basis of the averages from years 1990-2004 and actual communities formed during the years 1991 and 2004 in spring barley at different crops rotation system positions; (A) in the spring for 1990-2004, (B, C) before harvest for 1990-2004, (D) in the spring for 1991, (E, F) before harvest for 1991, (G) in the spring for 2004, (H, I) before harvest for 2004; position of spring barley (position): A-p - in crops rotation system A after potato, B-b - in crops rotation system B the first time after spring barley, B-bb - in crops rotation system B the second time after spring barley; $\mathrm{H}_{a-\text { density }}$ - family of Rényi indexes computed on the bases of weeds density, $\mathrm{H}_{a \text {-biomass }}$ - family of Rényi indexes computed on the bases of weeds biomass 

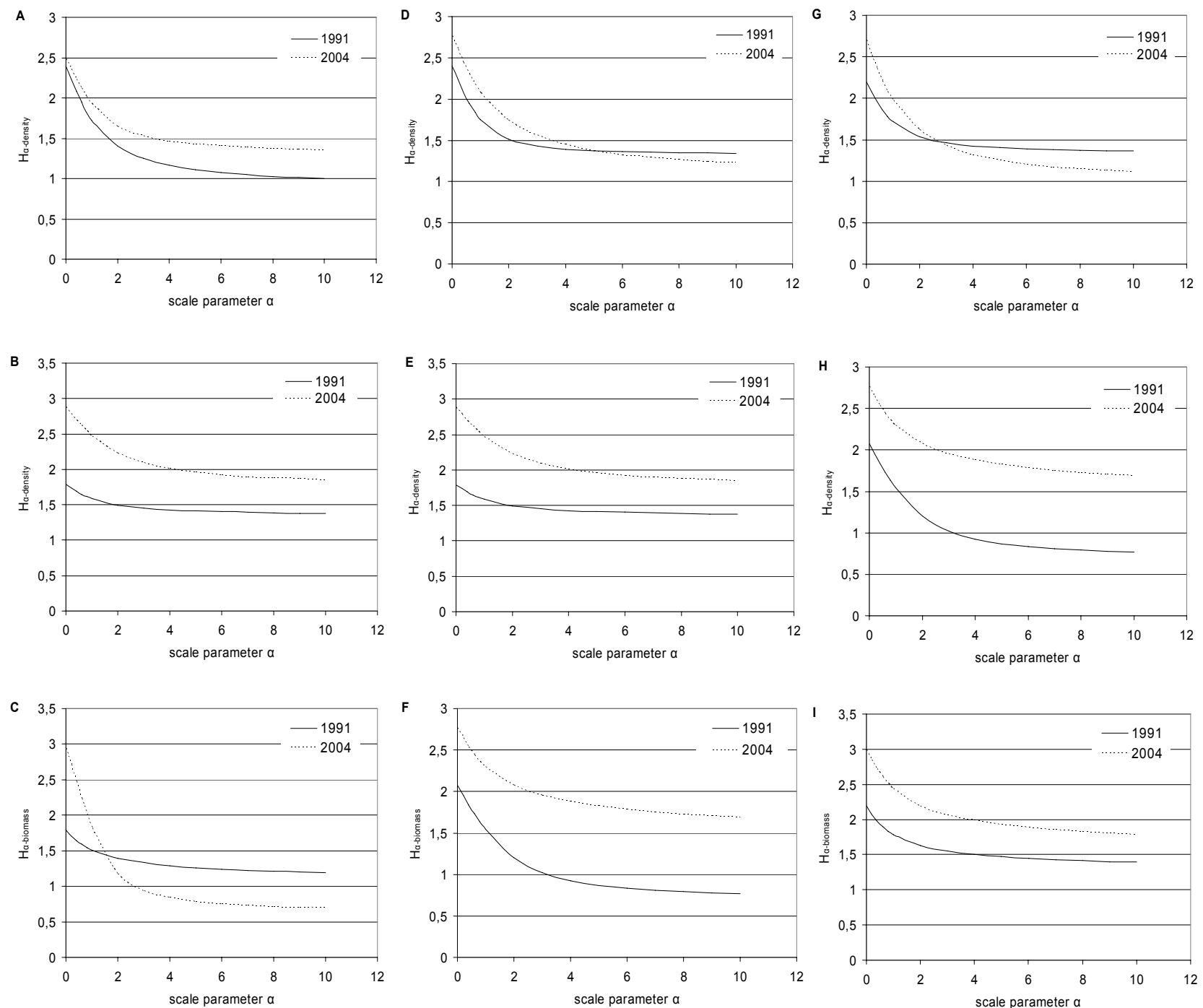

Fig. 3. Comparison of weed communities species diversity in spring barley forming at the same plot at the beginning (1991) and at the end (2004) of the experimental period based on diversity profile by Rényi; (A) in the spring for A-p, (B, C) before harvest for A-p, (D) in the spring for B-b, (E, F) before harvest for B-b, (G) in the spring for B-bb, (H, I) before harvest for $\mathrm{B}-\mathrm{bb}$; position of spring barley (position): A-p - in crops rotation system A after potato, B-b - in crops rotation system B the first time after spring barley, B-bb - in crops rotation system B the second time after spring barley; $\mathrm{H}_{a-\text { density }}-$ family of Rényi indexes computed on the bases of weeds density, $\mathrm{H}_{a \text {-biomass }}$ - family of Rényi indexes computed on the bases of weeds biomass 

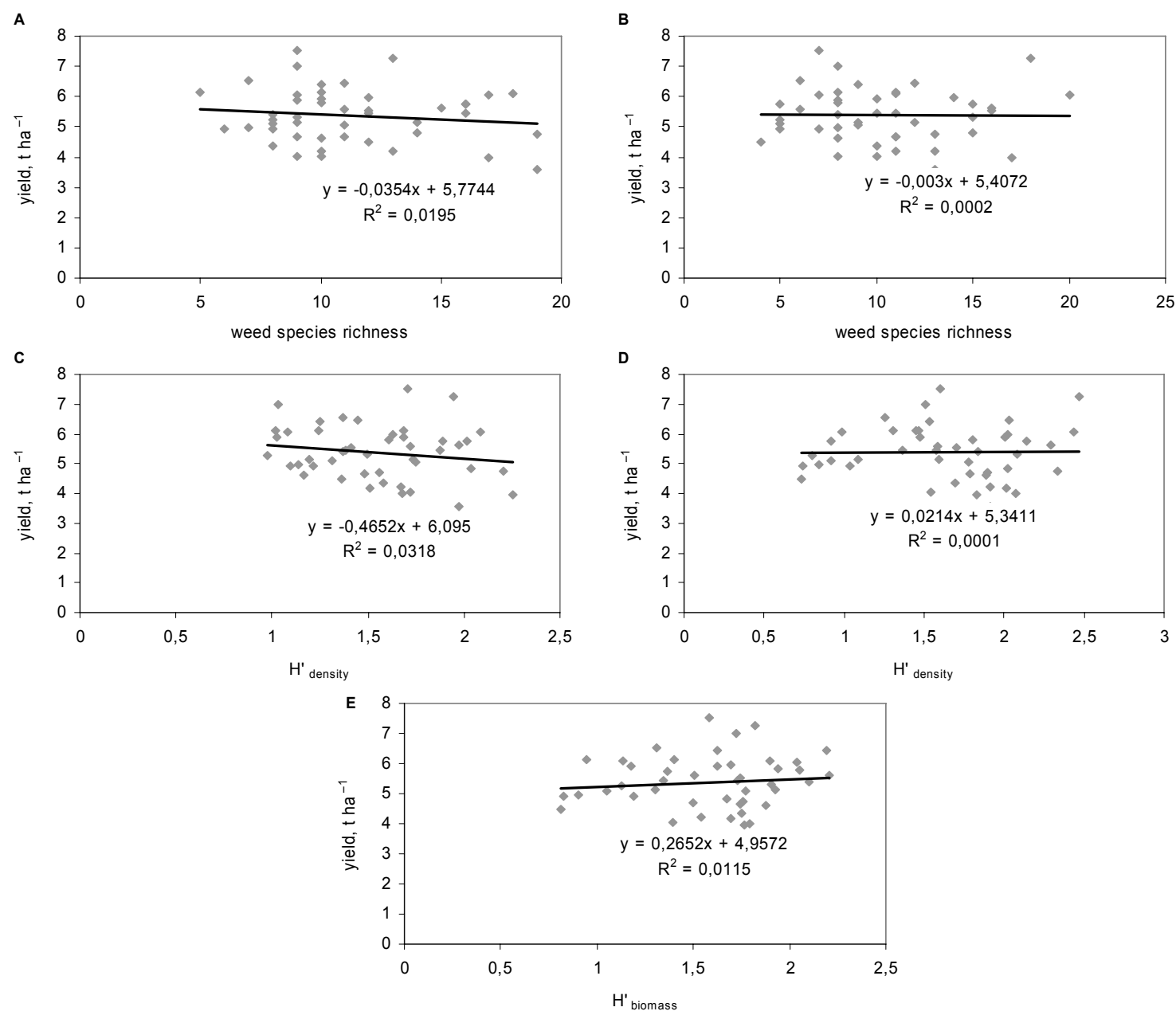

Fig. 4. Correlation of spring barley harvest with weed species diversity in the spring (A, C) and before harvest (B, D, E); H'density - Shannon-Wiener diversity index computed on the bases of weeds density, H' biomass - Shannon-Wiener diversity index computed on the bases of weeds biomass; $\mathrm{R}^{2}(*)$ - determination coefficient (significant at $\mathrm{p}=0,05$ )

\section{DISCUSSION}

Among phytosociologists and herbologists dealing with the dynamics of weed growth in time periods encompassing a few decades and under the influence of various factors, the opinion exists that the general level of weed infestation measured by weed coverage of the crop field and the number of weeds is not subject to significant changes, while as a consequence of changes taking place in agriculture the number of species in weed communities decreased and the dominance of a few taxa increased (A $1 \mathrm{~b} \mathrm{rec} \mathrm{h} \mathrm{t,} \mathrm{1995).} \mathrm{L} \mathrm{o} \mathrm{s} \mathrm{o} \mathrm{s} \mathrm{o} \mathrm{-}$ $\mathrm{v}$ á et al. (2004) confirmed the decrease in natural richness of species in the fields of the Czech Republic and Slovakia during the years 1954-2003 using a highly significant correlation coefficient $(\mathrm{r}=-0.768)$. In the presented experiment of much shorter duration, i.e. 15 years, limited in space and additionally based on different methodological assumptions, no decrease in the richness of species was found in the studied phytocenoses over time or under the influence of less favorable spring barley positioning in the rotation system, and even - with the exception of the position after potato in the spring - a significant straight line increase in the number of species in the spring and summer communities was confirmed. The increase in the number of weed species was also found by W a n i c et al. (2005) in an 11-year experiment with oats positioned after potatoes and twice in succession after oats, without herbicide protection, and by Feledy $\mathrm{n}-\mathrm{Szewczyk}$ (2008) in a 12-year experiment with ecological cultivation of winter wheat.

The richness of species is currently still the most frequently applied measure of weed diversity in agricultural studies (Z aw i ślak, 1997; B le c har c z y k et al. 2000; B u c zy ń s ki and Mark s, 2003; Lososová et al. 2004; Ada miak, 2007; K a a r and Freyer, 2008). Also, an increasing number of 
studies appear where such analysis is based on indicators considering quantitative proportions between species, which is more justified in assessment of the functioning of phytocenoses. The most frequently used measure is the Shannon-Wiener diversity index based on density of individuals representing individual species in the community ( $\mathrm{S}$ te ven sen et al. 1997; Wesołowski et al. 2003; Jędruszczak and Antoszek, 2004; Stupnicka-Rodzynkiewic z et al. 2004; W anic et al. 2005; J a strzę bska et al. 2006; Feledyn-Szewczyk, 2008), biomass produced by those species ( $\mathrm{J}$ a s trzę bs ka et al. 2007) or coverage of the field by plants of individual species ( $\mathrm{J}$ a s t r z ę b s k a et al. 2009). From the agricultural perspective, considering that the competitive power of weeds against the crop is determined by the biomass and even quite numerous but small seedlings are of little harm, the two latter approaches seem more reasonable. In the presented studies, the Shannon-Wiener indices calculated on different bases (density and biomass) showed high convergence. This is surely justified by the fact that Chenopodium album, which was the most numerously represented weed species for all three positions, also dominated in the community in terms of the biomass produced. A similar correlation was established by J a s tr z ę bska et al. (2007) for weed communities in field beans, although logic indicates that this does not have to be the rule.

Kostrzewska and Wanic (2005) draw attention to the fact that the Shannon-Wiener index value for weed communities developing in spring barley increases with the consecutive return of spring barley to the same field in the rotation system with its $75 \%$ share, but for the treatment where the cereal was positioned after potato in the rotation system with its $50 \%$ share, the value of the index was higher than in case of successive cultivation and lower than in case of successive cultivation twice after spring barley in the same field. We s ołowski et al. (2003) recorded a slightly higher diversity of weeds in winter wheat when it was cultivated in monoculture than in the crop rotation system, but J ę dru s z c zak and A nto s zek (2004) prove that the cultivation of wheat in monoculture has a degenerative influence on weed communities and with the passage of years a decrease in biodiversity occurs. Our own studies indicate a rather minor decrease in the diversity of weeds in spring barley under poorer crop rotation conditions. S tevensen et al. (1997) report that both the number of species and their diversity measured using the Shannon-Wiener index were higher in the field of barley cultivated in a 3-year fodder crop rotation system than in monoculture (irrespective of the weed control method). Stupnicka-Rodzynkiewicz et al. (2004), on the basis of their studies with winter wheat and spring barley in different crop rotation systems, conclude that the influence of the rotation system on the diversity of a weed community develops differently depending on the crop species and its development phase, although the differences are small. The papers by Stupnicka-Rodzynkiewicz etal. (2004) and Feledyn-Szewczyk (2008) indicate that the biodiversity of weeds in the summer is larger than in the spring, which was also reflected in the average values in our studies, but Jędruszczak and A n to s z e k (2004) recorded opposite relations in the monoculture of wheat, while Jastrzębska et al. (2006) point at different effects in that aspect obtained for three different spring cereals.

The studies by W a n i c et al. (2005) on weed communities in oats indicate higher year-to-year variability of weed biodiversity than that depending on previous crops differing extremely in quality (potato and oats second time after oats) and the differences between biodiversity of species determined in the spring and in the summer developed in different ways during different years.

In our own studies, the Shannon-Wiener index values formed a significant increasing year-to-year trend only for the summer communities in the positions with successive cultivation of spring barley twice after spring barley; in other cases, the correlation was positive but insignificant. W a n i c et al. (2005) determined the increasing, during a period of 11 years, trend of the Shannon-Wiener index (according to density) values for summer weed communities in oats cultivated after potato and after oats. A similar trend was determined by J a strzę bska et al. (2006) in oats cultivated in the component of potato - Persian clover - oats, but it did not apply to spring barley and the mix of barley with oats cultivated in the same sequence. In the referred experiments (W a n i c et al. 2005; J a strzębska et al. 2006), the crops were not protected against weeds. In the earlier referenced studies on winter wheat, Feled y $\mathrm{n}-\mathrm{S} \mathrm{zewczyk}$ (2008) did not determine the mathematical trends, but she mentioned that the values concerned indicated an increase in weed biodiversity (indicator H') in spring and summer communities during 12 years of ecological cultivation with weed control by means of a weed harrow. L u n d k v is t et al. (2008), on the basis of an experiment with various crops cultivated in two rotation systems under an organic farming system, report that biodiversity of weeds measured by Simpson index (C) did not show a significant year-to-year trend.

The variability of biodiversity measures (number of species and Shannon-Wiener indexes) was strongly correlated with weather - positively with precipitation and negatively with temperature, which is also confirmed by the studies conducted by $\mathrm{W}$ a n i c 
et al. (2005) and J a s tr zę b s k a et al. (2006), similar in methodology and habitat conditions.

Authors increasingly more often refer to the concept formulated by Rényi (1961) in assessment of biodiversity of organism communities, including plant communities, undertaken in ecological studies on various formations. According to that concept, the biodiversity of a community of organisms is multidimensional in character and we can say about one community that it is more diversified than the other if it is more diversified at all levels of biodiversity, starting with level $a=0$, at which the index is the derivative of the number of species, through level 1 , which corresponds to Shannon-Wiener (H') diversity index, level 2 - that involves Simpson index (C) and the level of "infinity", which is the derivative of Berger-Parker diversity index (Tóthmérés z, 1995; K in d t et al. 2006). The diversity profiles can be used for comparison of actual phytocenoses as well as abstract groupings while maintaining homogeneity of material and procedures. In the study presented here, an attempt was made to apply both these approaches. As regards organization, they seem to correspond with the assessment made on the basis of richness of species and Shannon-Wiener index as concerns the major year-to-year diversities between actual phytocenoses, then between positions, as well as minor deviations in case of comparing "artificial" systems established on the basis of the averaged results from the long-term period. Observations based on the Rényi profile should be treated as signals, because only the phytocenoses from the extreme years of the experiment were used for comparison of the actual phytocenoses. It is also difficult to confront our own findings in that area with the opinions expressed by other authors because, while in the available literature there are articles comparing forest (K ind t et al. 2006) or meadow communities (Szoszkiewicz and Szoszkiewicz, 1999) using Rényi entropy, attempts at finding articles discussing weed communities from that perspective were not successful.

The composition of species in the analyzed communities, particularly the set of permanent species and species occurring during the most abundant years, was to a large extent consistent with other reports $(\mathrm{Z} \mathrm{a} \mathrm{w} \mathrm{i} \mathrm{-}$ śla k, 1997; B u c z y ński and Mark s, 2003, K o strzewska and Wanic, 2005; Jastrzębska et al. 2006; A d a miak, 2007). In view of the opinion of Latowski (2002), these were species very common and common in Poland. In our own studies, Chenopodium album was ranked first as regards the density and biomass produced in all the three positions analyzed. This taxon is considered to be one of more dangerous competitors of barley (Kostrzewska and W a i c, 2005), although numerous papers indicate that with the saturation of the rotation systems with cereals, mainly spring ones, in case of spring barley the dominance of Avena fatua increases (B le c harczy k et al. 2000; B u czy ński and Marks, 2003). In view of other studies ( $\mathrm{Z}$ a w is śla k, 1997; Kostrzewska and Wanic, 2005) this is not the rule because even in unprotected monoculture of barley Avena fatua may occupy a farther place in the structure giving priority to numerous other taxa, mainly dicotyledonous, similar to the situation in the here presented own studies.

In the presented studies, similar to the earlier studies on phytocenoses of cereals (Wanic et al. 2005; J a strzębska et al. 2006), the significance of the correlation between barley yield and weed diversity was not confirmed.

\section{CONCLUSIONS}

1. The richness of weed species increased linearly at all plots during the 15-year period.

2. Chenopodium album was a constant and dominant species in terms of weed species density and biomass year after year.

3. The quality of the plot had no clear influence on the diversity of weeds in barley.

4. Weed diversity showed high year-to-year variability and a positive correlation with the amount of precipitation and a negative correlation with temperature during the period of the study.

5. Significance of the correlation between the productivity of barley and weed diversity was not confirmed.

\section{REFERENCES}

Adamiak E., 2007. Struktura zachwaszczenia i produktywność wybranych agrocenoz zbóż ozimych i jarych w zależności od systemu następstwa roślin i ochrony łanu. / Weed infestation structure and productivity of chosen winter and spring crop agrocenoses depending on vegetal succession and standing corn protection. Rozprawy i Monografie 129, Wyd. UWM, Olsztyn.

Albrecht H., 1995. Changes in the arable weed flora of Germany during the last five decades. In: Proceedings $19959^{\text {th }}$ EWRS Symposium on Challenges for Weed Science in a Changing Europe, Budapest, Hungary: 41-48.

Altieri M.A., 1999. The ecological role of biodiversity in agroecosystems. Agr. Ecosyst. Environ. 74: 19-31.

Andreasen C., Stryhn H., 2008. Increasing weed flora in Danish arable fields and its importance for biodiversity. Weed Res. 48: 1-9.

Blecharczyk A., Małecka I., Skrzypczak G., 2000. Wpływ wieloletniego nawożenia, zmianowania 
i monokultury na zachwaszczenie jęczmienia jarego. / Effect of long-term fertilization, crop rotation and continuous cropping on weed infestation of spring barley. Ann. UMCS, Sect. E, 55, suppl.: 17-23.

Braun-Blanquet J., 1964. Pflanzensoziologie. Grundzuge der Vegetationskunde. 3rd edn. Springer-Verlag, Vienna, New York.

Buczyński G., Marks M., 2003. Zachwaszczenie i plonowanie jęczmienia jarego w płodozmianach i monokulturze. / Spring barley weed infestation and yield in crop rotation and monoculture. Zesz. Probl. Post. Nauk. Rol. 490: 41-47.

Cheffings C.M., Farrell L., Dines T.D.,. Jones R.A., Leach S.J., McKean D.R., Pearman D.A., Preston C.D., Rumsey F.J., Taylor I., 2005. The Vascular Plant Red Data List for Great Britain. Species Status 7. Joint Nature Conservation Committee, Peterborough, UK.

Feledy n-Szew czyk B ., 2008. The changes of biodiversity of weed flora in organic system in the years 19962007. J. Res. Appl. Agric. Eng. 53: 63-68.

Hochół T., 2003. Chwasty czy rośliny towarzyszące uprawom? / Weeds or plants accompanying crops? Pam. Pul. 134: 89-96.

Hooper D.U., Chapin F.S., Ewel J.J. Hector A., Inchausti P., Lavorel S., Lawton J.H., Lodge D.M., Loreau M., Naeem S., Schmid B., Setala H., Symstad A.J., Vandermeer J., Wardle D.A., 2005. Effects of biodiversity on ecosystem functioning: a consensus of current knowledge. Ecol. Monogr. 75: 3-35.

Hyvönen T., 2004. Temporal and spatial variation in weed community of spring cereal fields. Academic dissertation, University of Helsinki, Finland.

Jastrzębska M., Bogucka B ., Hruszka M., 2007. Następstwo roślin i proekologiczne sposoby regulacji zachwaszczenia a bioróżnorodność chwastów w bobiku. / Crop sequence and environment-friendly weed control methods versus weed biodiversity in faba bean fields. Acta Agrophys. 10: 357-371.

Jastrzębska M., Szarejko T., Hołdyński Cz., Jastrzębski W.P., 2009. Species diversity in grassland communities under different habitat conditions. Pol. J. Natur. Sc. 24: 43-59.

Jastrzębska M., Wanic M., Kostrzewska M.K., Nowicki J. 2006. Biological diversity of cereal fields. Pol. J. Natur. Sc. 12: 499-518.

Jędruszczak M., Antoszek R., 2004. Sposoby uprawy roli a bioróżnorodność zbiorowisk chwastów w monokulturze pszenicy ozimej. / Tillage systems and biodiversity of weed communities in winter wheat monoculture. Acta Sci. Pol., Agricult. 3: 47-59.

Ka a r B., Freyer B., 2008. Weed species diversity and cover-abundance in organic and conventional winter cereal fields and 15 years ago. 2nd Conference of the
International Society of Organic Agriculture Research ISOFAR, June 18-20, 2008, Modena, Italy, Archived at http://orgprints.org/view/projects/conference.html

Kindt R., VanDame P., Simons A.J., 2006. Tree diversity in western Kenya: using profiles to characterise richness and evenness. Biodiversity and Conservations, 15: 1253-1270.

Kostrzewska M.K., Wanic M., 2005. Zbiorowiska chwastow jęczmienia jarego w zależności od jego miejsca w płodozmianie. / Communities of spring barley weeds depending on its place in the rotation system. Fragm. Agron. 2: 90-96.

Lehman C.L., Tilman D., 2000. Biodiversity, stability, and productivity in competitive communities. Am. Natur. 156: 534-552.

Lososová Z., Chytrý M., Cimalová Š., Kropáč Z., Otýpková Z., Pyšek P., Tichý L., 2004. Weed vegetation of arable land in Central Europe: gradients of diversity and species composition. J. Veg. Sci. 15: 415-422.

McCann K.S., 2000. The diversity - stability debate. Nature, 405: 228-233.

Mirek Z., Piękoś-Mirek H., Zając A., Zając M., 1995. Vascular plants of Poland. A checklist. Instytut Botaniki im. W. Szafera w Krakowie, PAN.

Rényi A., 1961. On measures of information and entropy. In: Proceedings $19604^{\text {th }}$ Berkeley Symposium on Mathematics, Statistics and Probability, Berkeley, USA: 547-561.

Shannon C.E. 1948. A mathematical theory of communication. The Bell System Technical Journal 27: 379423.

Skrzypczak G., Adamczewski K., 2002. Najgroźniejsze chwasty świata $\mathrm{w}$ roślinach uprawnych XXI wieku. / The most dangerous weeds in arable crops of the 21st century. Prog. Plant Protection/Post. Ochr. RoŚlin, 42: 358-367.

Smith R.G., Gross K.L., Robertson G.P., 2008. Effect of crop diversity on agroecosystem function: crop yield response. Ecosystems, 11: 355-366.

Stevenson F.C., Légčre A., Simard R.R., Angers D.A., Pageau D., Lafond J., 1997. Weed species diversity in spring barley varies with crop rotation and tillage, but not with nutrient source. Weed Sci. 45: 798-806.

Stupnicka-Rodzynkiewicz E., Stępnik K., Lepiarczyk A., 2004. Wpływ zmianowania, sposobu uprawy roli i herbicydów na bioróżnorodność zbiorowisk chwastów. / Effect of the crop rotation, tillage method and herbicides on the biodiversity of weed communities. Acta Sci. Pol., Agricult. 3: 235-245.

Szoszkiewicz K., Szoszkiewicz J., 1999. Comparison of diversity of lowland grassland vegetation communities in Poland. Rocz. AR w Poznaniu, Melior. Inż. Środ. 20: 293-298. 
Tóthmérész B., 1995. Comparison of different methods for diversity ordering. J.Veg. Sci. 6: 283-290.

Türe C., Böcük H., 2008. Investigation of threatened arable weeds and their conservation status in Turkey. Weed Res. 48: 289-296.

Wanic M., Jastrzębska M., Kostrzewska M.K., Nowicki J., 2005. Analiza zbiorowisk chwastów za pomocą wybranych wskaźników biologicznych. / Analysis of weed communities using selected biological indicators. Acta Agrobot. 58: 227-242.

Wanic M., Jastrzębska M., Kostrzewska M.K., 2010. Influence of crop rotation and meteorological conditions on density and biomass of weeds in spring barley. Acta Agrobot. (in press).

Wesołowski M., Jędruszczak M., Cierpiała R., 2003. Organizacja chwastów w zależności od systemu uprawy dwóch odmian pszenicy ozimej. / Arrangement of weed community in dependence on plant cultivation system of two winter wheat cultivars. Acta Agrophys. 1: 787-793.

Wiener N., 1948. Cybernetics, or control and communication in the animal and the machine. The MIT Press, Cambridge, MA, USA.

Zarzycki K., Mirek Z., 2006. Red list of plants and fungi in Poland. Instytut Botaniki im. W. Szafera, PAN, Kraków.

Z awiślak K., 1997. Regulacyjna funkcja płodozmianu wobec chwastów w agrofitocenozach zbóż. / The regulatory role of crop rotation in weed control in cereal agrophytocenoses. Acta Acad. Agricult. Tech. Olsten., Agricult. 64: 81-100.

\section{Wpływ płodozmianu i warunków meteorologicznych na bioróżnorodność zbiorowisk chwastów w jęczmieniu jarym (Hordeum vulgare $\mathrm{L}$.)}

\section{Streszczenie}

W pracy przedstawiono analizę zmian bioróżnorodności chwastów w jęczmieniu jarym uprawianym w latach 1990-2004 w płodozmianie z 25\% udziałem tego zboża (ziemniak - jęczmień jary - groch siewny - pszenżyto ozime) w następstwie po ziemniaku i w płodozmianie z 75\% jego udziałem (ziemniak - jęczmień jary - jęczmień jary - jęczmień jary) w jednoi dwukrotnym następstwie po sobie. W eksperymencie nie stosowano ochrony przed chwastami. Corocznie, wiosną (w pełni wschodów zboża) i przed zbiorem oznaczano skład gatunkowy i liczebność poszczególnych gatunków chwastów, a przed zbiorem także ich biomasę. Na tej podstawie ustalono stałość pojawiania się gatunków w latach, wskaźniki różnorodności gatunkowej Shannona-Wienera i profile różnorodności wg Renyiego. Bogactwo gatunkowe chwastów wzrastało liniowo w ciągu 15 lat we wszystkich stanowiskach. Jakość stanowiska nie miała wyraźnego i jednoznacznego wpływu na różnorodność chwastów w jęczmieniu. Stałym w latach i dominującym gatunkiem było Chenopodium album. Różnorodność chwastów wykazywała dużą zmienność w latach badań oraz dodatnią korelację z ilością opadów i ujemną z temperaturą w okresie badań. Nie potwierdzono istotności związku wydajności jęczmienia z różnorodnością chwastów. 
